\title{
ANALISIS VISUALISASI IKLAN MINUMAN SEGAR MELALUI PENDEKATAN RELASI UNSUR OBJEK (Studi Kasus: Iklan Sprite Versi Kenyataan Yang Menyegarkan)
}

\author{
Irfandi Musnur \\ Program Studi Desain Komunikasi Visual \\ Fakultas Desain dan Seni Kreatif, Universitas Mercu Buana \\ Jalan Meruya Selatan No.1 Kembangan Jakarta Barat
}

\begin{abstract}
Abstrak. Peranan visualisasi dalam iklan sangat penting guna membentuk pesan yang kreatif bagi konsumen. Bagi produk-produk seperti makanan dan minuman, iklan menjadi salah satu media promosi yang sangat lumrah digunakan. Salah satunya adalah brand minuman terkenal SPRITE. Brand minuman segar ini telah banyak menampilkan iklan-iklan kreatif dengan tampilan unsur-unsur visual yang menarik. Sebagai upaya memberikan sumbangsi pemikiran dalam visualisasi pesan dalam konteks komunikasi visual. Brand Sprite menjadi objek yang menarik untuk dibahas melalui pandangan toeritik visualisasi relasi unsur. Teoritik relasi unsur dapat memberikan pemaknaan analitik tentang bagaimana pembentukan pesan melalui relasi unsur-unsur yang dimiliki, baik analitik maupun sinaktik. Versi Iklan Sprite yang akan dibahas adalah versi "kenyataan yang menyegarkan". Beberapa penelitian sebelumnya telah membahas versi iklan tersbut melalui analisis SEMIOTIKA. Pada penelitian ini akan membahas lebih kepada bagaimana relasi unsur visual pada komunikasi visual iklan Sprite versi "kenyataan yang menyegarkan". Penelitian ini dilakukan dengan pendekatan Metode kualitatif deskriptif dengan teknik pengumpulan data Observasi dan analisis Video iklan.
\end{abstract}

Keywords: Iklan Sprite, relasi unsur visual, kenyataan yang menyegarkan.

Abstract. The role of visualization in advertising is very important to form creative messages for consumers. For products such as food and beverages, advertising becomes one of the promotional media that is very commonly used. One of them is the famous beverage brand SPRITE. This fresh beverage brand has displayed many creative advertisements with attractive visual elements. In an effort to contribute thought in the visualization of messages in the context of visual communication. Brand Sprite becomes an interesting object to be discussed through the toeritic view of the visualization of elemental relations. Theoretic relations element can provide analytic meaning about how the formation of messages through the relations of the elements that are owned, both analytic and syntactic. The Sprite ad version that will be discussed is the "refreshing reality" version. Several previous studies have discussed this version of advertising through SEMIOTICS analysis. This research will discuss more about how the relation of visual elements in the visual communication of the Sprite ad version "refreshing reality". This research was conducted with a descriptive qualitative method approach with data collection techniques Observation and analysis of advertising video.

Keywords: Sprite advertisement, visual element relation, refreshing reality.

Correspondence author: Name, E-mail, City, and Country 


\section{PENDAHULUAN}

Produk minuman segar telah merambah ke penjuru dunia dengan berbagai macam jenis yang sangat beragam. Mulai dari minuman yang memiliki brand mendunia sampai pada minuman tiap negara. Munculnya dunia periklanan menjadi media utama untuk mempromosikan produk-produk minuman dan makanan. Salah satu brand minuman segar yang sangat dikenal masayarakat saat ini adalah salah satunya minuman segar bersoda "Sprite". Hampir seluruh lapisan masyarakat dunia pernah mengkonsumsi minuman bersoda, minuman ringan atau soft drink. Berbagai produk minuman berkarbonasi telah diproduksi dan salah satunya adalah brand Sprite versi "Cak Lontong Kenyataan Yang Menyegarkan". Produk iklan "Sprite versi Cak Lontong Kenyataan Yang Menyegarkan" adalah sederet versi iklan yang telah diproduksi oleh Sprite diantara versi lainnya. Brand Sprite merupakan brand minuman yang selalu berupaya mengikuti setiap trend massa kini. Versi iklan "kenyataan yang menyegarkan merupak bentuk peremajaan dari vesrsi-versi sebelumnya sebagai upaya mendekatkan diri dikalangan masyarakat. Ada beberapa seri iklan di versi tersebut yakni Beberapa penyajian serial tema tersebut di antaranya (1) seri Nyatanya, Hidup Gak Seserem Film Horror, (2) Nyatanya, Hidup Gak Sebombastis Film Aksi, (3) Nyatanya, Hidup Gak Kayak Drama Korea, (4) Nyatanya, Hidup Gak Seindah Medsos Selebriti.

Meskipun produk minuman Sprite masih memiliki posisi yang terbilang di bawah dari brand terkenal lainnya seperti coca'cola, namun jika dipandang dari sisi kreativitas visualisasi iklan, brand Sprite juga patut diperhitungkan. Dilangsir dari penelitian Mitaharoh menjelaskan bahwa "dominasi pasar minuman berkarbonasi di dunia sejak puluhan tahun yang lalu telah dikuasai oleh produk global dengan nama besar yaitu PT Coca Cola. Data Top Brand Index 2013 untuk kategori minuman bersoda Sprite sebanyak 19,3\%". Berdasarkan hal tersebut pemlihan objek penelitian tentang visualisasi iklan Sprite tidak berdasarkan pada data dominasi pasar tersebut, melainkan kemampun brand Sprite dalam menciptakan dan menyampaikan pesan komunikasi yang menarik. Kemenarikan pesan komunikasi tersebut tentu saja dibangun dengan kemampuan tim kreatif dan pemilihan ide unsur-unsur visual yang baik. Melalui proses kreatif tersebut mejadi hal yang menarik untuk didiskusikan dalam ranah akdemik. Untuk itu, kehadiran penelitian ini menjadi penting sebagai upaya melahirkan pemikiran-pemikiran baru dalam melihat pesan-pesan kreatif visual pada sebuah iklan Sprite. Pemikiran ini diharapkan dapat memberikan cara pandang baru dalam merancang sebuah media komunikasi visual dengan memperhatikan relasi-relasi unsur pesan itu sendiri. Relasi unsur merupakan sebuah pendekatan yang dapat melihat sebuah pesan komunikasi baik visual maupun verbal yang saling berhungan satu sama lain.

Berdasarkan hal tersebut, pada iklan ini menjadi menarik untuk dibahas melalui proses pembentukan visualisasi iklan Sprite dilihat pada relasi unsur pembentukannya hingga menciptakan sebuah makna. Iklan Sprite versi "kenyataan yang menyegarkan" memiliki perbedaan yang sangat menarik antara iklan Sprite yang lain yang telah dibahas oleh beberapa peneliti lainnya. Melalui penelitian ini akan mengungkap bagaimana relasi unsur visual pada komunikasi visual iklan Sprite versi "kenyataan yang menyegarkan".

Dengan menimbang latar belakang di atas, maka dirumuskan beberapa masalah dan pertanyaan penelitian sebagai berikut:

1. Bagaimana bentuk visualisasi pada iklan Sprite versi "kenyataan yang menyegarkan"?

2. Bagaimana bentuk relasi unsur yang digunakan dalam tiap visualisasi pada iklan Sprite versi "kenyataan yang menyegarkan"? 
3. Bagaimana pesan "kenyataan yang menyegarkan" dapat disampaikan melalui prinsip relasi unsur pada iklan Sprite tersebut?

\title{
METODE
}

Sebagai upaya dalam mencapai hasil penelitian yang terstrutur, maka penelitian ini dilakukan dengan metode kualitatif deskriptif (pendekatan studi kasus). Pemilihan metode ini melalui pertimbangan yang sangat matang berdasarkan penelusuran di berbagai literatur tentang metode penelitian itu sendiri. Penelitian dengan metode kualitatif memungkinkan peneliti dalam menggali data yang bersifat deskriptif yang bersumber baik dari teks maupun nonteks, baik tulisan maupun lisan dengan pengamatan yang mendalam (Bogdan and Biklen). Dalam metode penelitian kualitatif dibagi atas beberapa bentuk penelitian salah satunya Studi Kasus (Denzin and Lincoln). Bentuk pendekatan ini sangat relevan dalam menemukan faktafakta yang mendalam, berdasarkan hal tersebut maka pendekatan tersebut perlu untuk digunakan pada penelitian ini. Berbeda dengan penelitian kuantitatif, penelitian kualitatif memiliki khasanah pengamatan mendalam dan pemaknaan yang kuat terhadap sebuah kasus penelitian (Creswell). Kemandirian riset sangat kental pada metode ini, sebagai bentuk analisis yang dapat digunakan pada kasus-kasus pengetahuan sosial. Kesimpulan yang dapat diangkat dapar bersifat pemaknaan dalam pandangan tertentu sehingga melahirkan variabel-variabel kebenaran yang lebih kaya. Hal ini dapat ditelusuri dengan amatan pada ungkapan bahasa dan peristilahannya dalam manusia (Kirk et al.).

Sugiyono dalam litarasinya mengatakan bahwa untuk memahmai penelitian kualitatif dapat dilihat pada perkembangan pemikiran postpositivism. Sugiono membeberkan pandangan bahwasanya metode kualitatif dalam penelitian memusatkan peneliti sebagai instrumen yang sangat penting. Setiap data yang ditemukan dalam penggalian dengan pendekatan kualitatif, dipadukan berdasarkan kebutuhan fakta yang akan disimpulkan. Peran peneliti menjadi subjek utama dalam meramu dan menyimpulkan sebuah penelitian dengan pola induktif ataupun generalisasi.

\begin{abstract}
"Penelitian kualitatif menyusun desain yang secara terus menerus disesuaikan dengan kenyataan lapangan. Jadi, tidak menggunakan desain yang telah disusun secara ketat dan kaku sehingga tidak dapat diubah lagi. Hal itu disebabkan oleh beberapa hal. Pertama, tidak dapat dibayangkan sebelumnya tentang kenyataan-kenyataan ganda di lapangan; kedua, tidak dapat diramalkan sebelumnya apa yang akan berubah karena hal itu akan terjadi dalam interaksi antara peneliti dengan kenyataan; ketiga, bermacam sistem nilai yang terkait hubungan dengan cara yang tidak dapat diramalkan" (Sugivono).
\end{abstract}

Penelitian Analisis Visualisasi Iklan Minuman Segar melalui Pendekatan Relasi Unsur Objek (Studi Kasus: Iklan Sprite Versi Kenyataan Yang Menyegarkan) akan dibahas melalui pendekatan teori Relasi Unsur. Kajian teoritik relasi unsur hanya sebatas melihat relasi-relasi yang ada pada sebuah media komunikasi visual. Berbeda dengan kajian Semiotika pencapaian pada maka dan interprestasi pada setiap tanda, pada penelitian ini hanya sebatas mengungkap bagaimana sebuah relasi-relasi unsur pada sebuah media komunikasi visual dapat saling menegasikan. Hal ini menjadi penting menjadi catatan penting penelitian sebagai batasan dalam analisis. Untuk itu prinsip-prinsip relasi unsur akan menjadi sangat penting dipahami 
untuk dapat digunakan sebagai sebuah pendekatan dalam membaca kasus dalam penelitian ini.

Analisis dan pembahasan dalam penelitian ini akan dimulai dengan membahas kerangka teoritik terlebih dahulu kemudian dilanjutkan dengan pemaparan data-data penelitian serta analisis searaca teoritik relasi unsur. Analisis relasi unsur akan dilakukan dengan pendekatan data studi referensi melalui video "iklan Sprite kenyataan yang menyegarkan" secara langsung. Analisis data dilakukan dengan mengedepankan potongan frame video setiap dan telaah setiap unsurnya. Hal ini dilakukan guna menemukan hasil yang relevan dan maksimal.

\section{HASIL DAN PEMBAHASAN}

\section{Konsep Teoritik Relasi Unsur}

Ketika kata merupakan unsur utama (komponen) dari sebuah kalimat untuk menceritakan sebuah makna, maka segala bentuk benda (entitas) yang tercermati oleh mata merupakan komponen bahasa visual. Hal ini berkaitan erat dengan peran indera sebagai sumber pencerapan terpenting. Kegunaan indera manusia sebagai penyerap informasi merupakan fitrah atau kodrat yang telah ditanamkan sejak aslinya. Bahkan dalam ilmu pencarian kebenaran (filsafat) Indera merupakan salah satu komponen penting pengetahuan. Bahkan pemikiran yang mengandalkan indera sebagai sumber pengetahuan telah disebutkan dalam istilah empirisme (pengetahuan pengalaman indera). Jauh setelahnya, ketika pengalaman indera merupakan salah satu sumber pengetahuan maka kajian bahasa (verbal maupun visual) turut menjadi perhatian dimana perannya sebagai salah satu cara merepresentasikan pengetahuan. Peran indera bukan menjadi perhatian dan pembahasan penting dalam modul ini, namun sebagai bentuk refleksi pengantar keterhubungan peluang yang muncul dari kemampuan indera dan relasi unsur suatu benda sebagai ungkapan kebenaran.

Kata merupakan unsur terpenting dalam struktur kalimat sebagai rangkaian makna, serta kata sendiri merupakan "perangkat" yang dapat menjelaskan makna sebuah benda. Kendati berpesannya kata berangkat dari benda (objek), namun jauh sebelumnya benda sejatinya sudah memiliki maknanya sendiri tanpa adanya kata (unsur). Benda atau objek dalam hal ini jauh sebelum adanya peran inderawi dan kehadiran manusia telah memiliki maknanya sendiri (memiliki unsurnya sendiri). Kehadiran manusia menjadi penting sebagai subjek yang berperan untuk menjelaskan sebuah objek atau benda sehingga lahirnya kata. Sebuah ilustrasi sederhana yang dapat dicermati adalah.

\section{"seekor kucing akan menghidar ketika ada percikan air".}

Seekor kucing tidak perlu memahami air dalam bentuk kata untuk mendapatkan pengetahuan untuk menghindar. Apabila unsur air hanya dapat dipahami melalui kata "air", maka seekor kucing tidak mampu menghindar dari siraman air. Dapat disimpulkan bahwa peran objek benda sebagai sumber pengetahuan dan bahasa (penyampai makna) secara unsur mampu menjelaskan dirinya sendiri tanpa adanya perantara "kata". Hal penting dalam hal ini objek telah memiliki unsur yang dapat dimaknai oleh kemampuan perangkat indera manusia, sehingga penting untuk memahami bagaiman peran Unsur-unsur benda dapat menjadi potensi "kosa kata visual". 
Mulanya ilmu pengetahuan muncul sebagai upaya manusia dalam mencari dan menjelaskan kemutlakan kebenaran. Awal kehidupan manusia penuh dengan misteri dan pertanyaan-pertanyaan akan dunia, mengapa saya hidup? Dan apa tujuann saya hidup?. Melalui berbagai macam misteri manusia melahirkan pemikiran kritis untuk mencoba memecahkan semua kebenaran dirinya dan dunia. Dalam pemecahan ini, manusia harus meminjam sebuah ucapan untuk menjelaskan makna semua bentuk entitas Dunia. Ucapan inilah disebut sebagai "bahasa" yang melahirkan berbagai macam ragam.

Tak elak lagi bahwasanya semua bidang Ilmu pengetahuan lahir sebagai metode untuk menjelaskan kebenaran entitas dunia dan diri manusia sendiri. IImu alam (sains) misalnya, upaya kebenaran yang dilakukan dengan menjelaskan secara materialistik sebuah benda. Misalnya "air" dapat dijelaskan dengan kode bahasa H2O. Bahasa sains membatasi potensi unsur air dengan kode kebenaran seperti yang dijelaskan tersebut. Berbeda dengan ilmu ekonomi menjelaskan "air" dengan entitas Aqua sebagai konsumsi manusia yang mesti dijadikan produk untuk dijual (kebenaran ekonomik). Namun bagi ilmu-ilmu Humaniora, desain dan seni, air bisa diartikan lebih luas dengan filosofis yang mendalam melalui pesan-pesan yang dibawanya. Bisa saja dalam ilmu alam air=H20, namun pada dasarnya semua orang mempunyai kebenaran pengalaman yang berbeda-beda dengan wujud air. Ketika air diceritakan kepada penduduk Aceh pasca Tsunami melanda, wujud makna air bisa menjadi sesuatu yang mengerikan (peran tradisi komunikasi fenomenologi). Makna kebenaran air pada dasarnya dapat memiliki arti yang sangat luas dan tak dapaat hanya disempitkan dengan bahasa $\mathrm{H} 2 \mathrm{O}$ oleh kebenaran sains. Bahkan kata air sendiri pun terbatas pada penjelasannya sebagai representasi makna. Peran pengalaman manusia tentang sebuah objek melahirkan

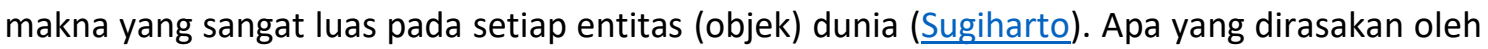
seseorang tak mampu dijelaskan dengan mutlak oleh kata, oleh kebenaran sains, ekonomi, dan ilmu-ilmu pengetahuan lainnya. "Maka dari itu, telah dijelaskan bahwa tak penting sebuah ilmu mencoba melabelkan apapun pada sebuah objek, pada dasarnya objek atau entitas apapun itu telah memiliki maknanya sendiri melalui unsur-unsur yang dimiliki". Berdasarkan hal tersebut patut dipahami bahwa peran rupa sebuah objek merupakan bahasanya sendiri, tergantung pengalaman sesorang maupun bagaimana rupa (visual) benda tersebut tersajikan.

Patut dipahami dan disimpulkan bahwa, dalam dunia interaksi manusia, peran komunikasi sangat penting. IImu pengetahuan masing-masing memberikan gambaran kebenaran melalui sudut pandang yang berbeda-beda. Pada dasarnya ilmu pengetahuan memerlukan bahasa untuk menjelaskan kebenarannya sebagai upaya komunikasi ke semua orang. Keterbatasan kata adalah masalah utama tidak utuhnya sebuah komunikasi, kata tak dapat merepresentasikan secara utuh makna melaikan hanya sebagian saja. sebagaimana dalam pesan sastra.

"cintaku seluas bumi dan jagad raya".

Pesan tersebut berupaya mewakili pesan cinta yang dalam seorang yang begitu besar sehingga dipadankan dengan luasnya jagad raya, kendati kebenaranya jauh lebih dahsyat dibanding ucapan tersebut. Di sinilah letak ketidakutuhan kata dapat menjelaskan makna, sehingga peran objek cinta itu sendiri dapat lebih dijelaskan dengan tindakan (visual) seperti kehadiran simbol-simbol visual. Simbol-simbol pun lahir tak pelik dari entitas relasi-relasi unsur yang terwakili oleh cinta itu sendiri yakni adalah hati. Hati dalah objek dimana perasaan cinta itu dapat dirasakan dan tumbuh disana, sehingga unsur hati adalah unsur cinta secara bahasa visual. Tak dapat dipungkiri, simbol ini lebih memiliki peran kuat dibanding dengan kata 
"cintaku seluas jagad raya" yang dapat menimbulkan penafsiran yang begitu luas. Bisa saja kata "cintaku seluas jagad raya" secara entitas dapat dimaknai dengan cinta untuk memiliki semua orang sejagad raya. Hal ini dapat disimpulkan bahwa peran relasi unsur sebuah objek dapat lebih efektif digunakan untuk merepresentasikan makna dibandingkan dengan kata, maka dari itu perlunya memahami penggunaan relasi unsur sebuah benda sebagai bahasa visual.

Relasi unsur benda sebagai upaya penggunaan bahasa komunikasi visual dapat dibedakan dalam 2 kategori:

1. Relasi Unsur analitik

2. Relasi Unsur sintakmatik

Kedua kategori tersebut merupakan pendekatan kritis yang dapat digunakan dalam menggunakan objek sebagai bahasa visual.

\section{Relasi Unsur Analitik'.}

Pendekan relasi analitik menjelaskan tentang peran unsur-unsur yang dimiliki sebuah objek sehingga dapat disebut sebagai benda. Analogi sederhana adalah sebuah mobil dapat dikatakan mobil dengan susunan unsur empat buah ban, bodi mobil, stir mobil dan komponen lainnya. Komponen ini merupakan unsur pembentuk objek pengetahuan tentan makna mobil. Susunan komponen tersebut pun harus tertata berdasarkan dengan prinsip susunan mobil, sendainya secara visual komponen tersebut diacak, belum tentu dapat disebut sebagai mobil. Relasi unsur analitik menampilkan pendekatan menarik dengan membuka ruang kritis dan kreatif bagi seorang desainer komunkasi visual untuk menggunakan unsur komponen tersebut sebagai bahasa visual. Komponen mobil bisa saja dapat secara utuh menjelaskan mobil secara Utuh tampa harus menampilkan mobil secara keseluruhan (kekuatan identifikasi visual, indeks, ikon, simbol). Mobil tidak perlu melahirkan semua komponen secara utuh. Secara unsur analitik, sebuah visual memiliki kecendrungan dominasi komponen visual yang dipahami sebagai iconic objek. Artinya, untuk menjelaskan objek mobil, dapat terwakili oleh relasi unsurunsur komponen dominan mobil (bisa jadi bodi, ban, dll). Prinsip dasar ini menjadi penting untuk dipahami sebagai bentuk kemampuan dalam melahirkan menyajikan visual. Relasi unsur analitik tidak berupaya merepresentasikan makna lain dari sebuah objek, melainkan pendekatan ini adalah mengefisienkan penyajian pesan visual. Selain berupaya efisiensi pesan visual, relasi unsur analitik bisa digunakan ke tahap pemaknaan kedua (simbolik).

Relasi unsur membuka peluang identifikasi visual untuk menjelaskan entitas keseluruhan objek. Konsep ini dapat dipadankan dengan konsep kesimpulan deduksi dari kausal khusus ke umum. Jika ditarik dari aspek bahasa sendiri, dapat dipahami bahwa sebuah kata terdiri dari unsur huruf sebagai pembentuknya. Apabila komponen huruf diacak maka berbeda pula maknanya, namun ketika sebuah kata dengan singkatan maka makna tetap utuh. Relasi unsur analitik memiliki prinsip yang sama sebagaimana sebuah kata.

\section{$L D R=$ Long Distance Relationship}

Ilustrasi kata tersebut menjelaskan bahwa susunan huruf LDR dapat sepadan dengan makna long distance relationship. Ilustrasi ini menjelaskan bagaimana kemampuan unsur objek dapat menjelaskan keseluran objek secara utuh. Selanjutnya, komponen yang dipisahkan dari keseluruhan objek bahkan dapat berpotensi dapat digunakan sebagai komponen bahasa lainnya, sebagai contoh mobil dengan komponen unsurnya dapat dipilah dan menjelaskan arti lainnya. 


\section{Relasi Unsur Sinektik}

Sinektik (Allport) dalam pengertiannya adalah sebuah pendekatan berfikir kreatif apa yang tampak berbeda dapat dipahami secara bersama. Istilah sinektik banyak digunakan dalam ranah ilmu-ilmu bahasa dan metode pendidikan. Pada penerapan dalam bahasa visual (komunikasi visual), khususnya dalam rana pendekatan relasi unsur objek dapat diartikan sebagai metode kalimat visual. Tak ubahnya kalimat dan kata, dapat dijelaskan bawha kata merupakan ranah unsur analitik, sedangkan kalimat adalah ranah unsur sinektik. Ilustrasi singkat untuk menggambarkan peran sinektik dapat kita jumpai pada poster-poster maupun iklan-iklan. Relasi-relasi visual dengan visual lainnya dapat menyampaikan pesan secara utuh meskipun terdiri dari beragam objek.

Dapat dipahami bahwa, dalam prinsip desain komunikasi visual, relasi unsur sinektik merupakan pendekatan merumuskan kalimat. Perbedaan mendasar adalah ketika kalimat dalam bahasa verbal memiliki pola S-P-O-K. Visual tidak berpatok pada prinsip struktur tersebut melainkan lebih ditekankan pada relasi citra untuk menggambarkan kesan. Pada tag line "Xenia mobil sahabat keluarga" juga menarik untuk menjadi pembahasan, dimana bentuk komunikasi ganda antara Visual dan bahasa kata. Terlihat jelas bahwa, tag line "Xenia mobil sahabat keluarga" tidak memiliki kemampuan yang utuh dalam membangun citra tanpa adanya bahasa visual. Seperti yang telah dijelaskan sebelumnya bahwa dalam tradisi komunikasi, sekalipun sebuah kata berupaya membangun citra tentu Visual memiliki kelebihan dalam keutuhan makna.

Relasi unsur sinektik berupaya membengun pemikiran kritis dan kreatif seorang desainer komuikasi visual dalam mengolah penyusunan struktur kalimat visual. Unsur-unsur visual dapat disusun sedemikian rupa hingga dapat menggambarkan pesan dan makna dengan jelas dan tercitra. Kembali menilik dalam ilmu semiotika Pierce yang telah dibahas sebelumnya bagaimana proses komunikasi terjadi, maka dapat disimpulkan bahwa komunikasi merupakan milik seorang penyampai pesan (Budiman). Pengorganisasaian bahasa visual dapat dilakukan melalui kemampuan menelaah tradisi-tradisi komunikasi visual (baik fenomenologi, sosial budaya, dll). Secara semiotik proses komunikasi dapat dipahami dan melalui relasi unsur memungkinkan reproduksi komunikasi visual.

\section{Analisis Data Penyajian Iklan Sprite versi "kenyataan yang menyegarkan"}

Iklan Sprite versi "kenyataan" disajikan dalam beberapa serial tema yang cukup menarik. Beberapa penyajian serial tema tersebut di antaranya (1) seri Nyatanya, Hidup Gak Seserem Film Horror, (2) Nyatanya, Hidup Gak Sebombastis Film Aksi, (3) Nyatanya, Hidup Gak Kayak Drama Korea, (4) Nyatanya, Hidup Gak Seindah Medsos Selebriti. Kehadiran iklan Sprite semakin menarik dengan kehadiran Cak Lontong sebagai vocal naratif iklan. Berdasarkan versi online media, iklan Sprite versi "kenyataan yang menyegarkan" dirilis di tahun 2018 dengan format serial.

Produk minuman Sprite mencoba menampilkan versi iklan yang berupaya lebih dekat kepada masyarakat sebagai tergetnya. Kehadiran serial tema dengan konten "kenyataan" direduksi dari beberapa kehidupan masyarakat. Konten-konten yang dihadirkan merupakan realitas kebiasaan Masayarakat masa kini. Kenyataan kehidupan tak seindah yang dibayangkan direpresentasikan melalui idealitas kehidupan darma Korea, dramatik film aksi dan bahkan seindah medsos selebriti. Di antara beberapa versi iklan Sprite kenyataan yang menyegarkan, salah satu iklan yang cukup mengganggu dan menarik untuk dibahas dalam riset ini adalah versi "kenyataan yang menyegarkan". Berbeda dengan konten-konten lainnya, secara hipotesis versi iklan tersebut murni hanya menggukan relasi-relasi unsur untuk menyampaikan sebuah 
pesan kenyataan yang menyegarkan. Bahkan unsur kalimat dalam backsound (oleh cak lontong) terkesan tidak memiliki pesan yang menarik dengan paduan visual pendukung kalimat.

Berdasarkan hal tersebut, kehadiran penelitian ini hanya berupaya mejelaskan bagaimana peran teoritik relasi unsur (analitik maupun sinektik) serta membedah keunikan dan kreativitas iklan tersebut. Beberapa pendekatan analisis pada dasarnya dapat digunakan seperti analisis Semiotik, namun pada perkembangannya relasi Unsur seringkali lebih lumrah digunakan dalam perancangan desain-desain komunikasi visual. Secara praktis penelitian ini berupaya menemukan bahwa relasi unsur memiliki kesederhanaan dalam menempatkan serta mengolah unsur visual dan kalimat sebagai sebuah pesan. Telah ditelaah bersama bahwa pada dasarnya unsur kata maupun kalimat memiliki upaya yang setara dalam menyampaikan makna meskipun tak setara. Visual dapat menjelaskan makna yang lebih cenderung pada entitas sebenarnya sedangkan kata merupakan kesimpulan pragmatis untuk sebuah esensi benda. Menariknya pada kasus iklan Sprite versi "kenyataan yang menyegarkan" dapat dibahas secara padu melalui pendekatan relasi unsur mengingat penggunaan kalimat dan visual yang bersamaan.

Iklan versi "kenyataan yang menyegarkan" dirils dengan durasi kurang lebih 30 detik dengan format video. Selain tampilan pesan visual, video iklan ini pun diisi dengan unsur pesan teks dan narasi vokal oleh "cak lontong". Catatan kalimat dalam iklan tersebut adalah sebagai berikut ;

"(-0.30 s) Hay guys! Ayo berfikir jernih, (-0.26 s) Apa iya mencampur sendiri es batu , rasa lemon, $(-0.23 \mathrm{~s})$ dan Gelembung, $(-0.22 \mathrm{~s})$ bisa seenak dan se-nyegerin segelas Sprite. (-0.19 s), Boleh aja dicoba, (-0.17 s) Tapi nyatanya susah, (-0.16) Menurut kamu info ini ngga penting, (-0.13) Nyatanya kamu jadi nonton iklan ini selama lebih dari 20 detik, (-0.08) dan sekarang kamu jadi haus dan pengen minum Sprite, (-0.2) Srite nyatanya Nyegerin.

Kalimat tersebut tidak hanya ditampilkan secara teks pada iklan namun juga dipertegas dengan backsound vokal oleh "cak lontong". Setiap potongan kalimat per-detik saling relasi dengan visual yang ditampilkan. Jika disimak secara seksama, potongan-potongan kalimat tersebut dapat diurut secara bersamaan dengan visual iklan sebagai berikut,

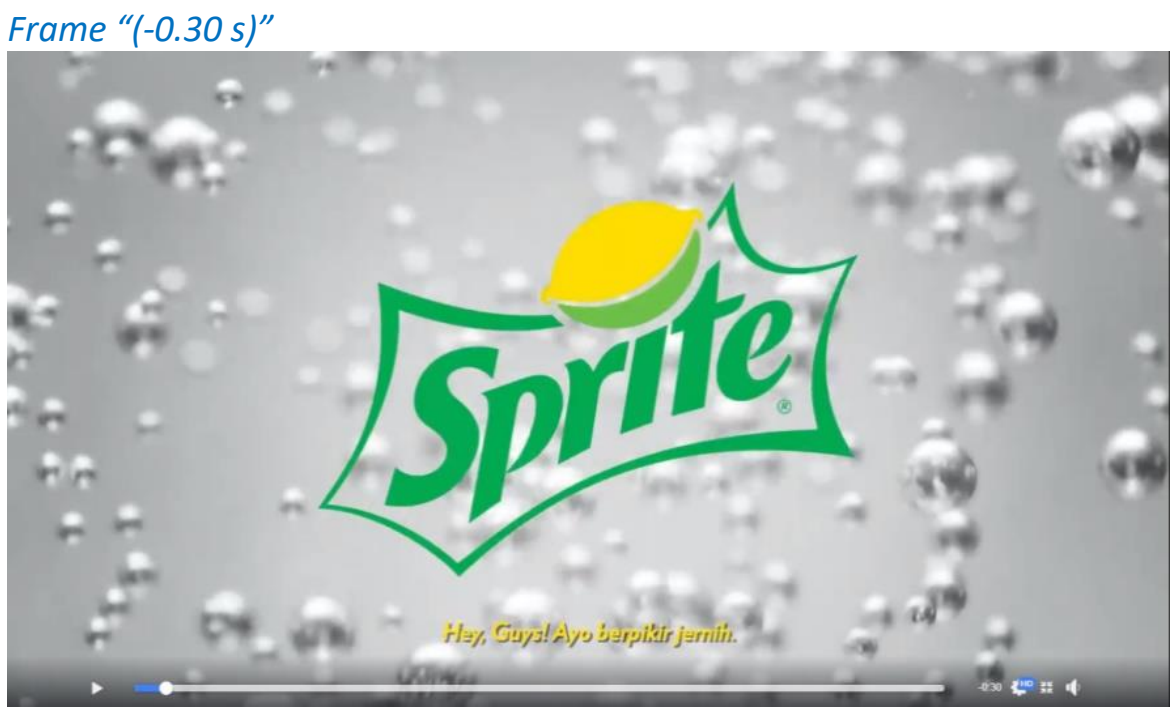

Gambar 1. Potongan iklan -0.30 Detik (Sumber

https://web.facebook.com/Spriteid/videos/872091522923549/?v=872091522923549) 
Pada potongan kalimat "(-0.30 s) Hay guys! Ayo berfikir jernih, ditampilkan dengan visualisasi yang dapat disimak pada gambar di atas. Unsur-unsur yang dimunculkan adalah logo Sprite, visualisasi background gelembung dan stilasi lemon. Berdasarkan teoritik relasi unsur analitik dan sinektik pembacaan potongan dalam iklan ini baik dari segi kalimat maupun visual dapat diuraikan dan diterjemahkan sebagai berikut:

1. Relasi unsur analitik frame $(-0.30 \mathrm{~s})$ : Berdasarkan prinsip unsur analitik yakni unsur-unsur pendukung tanda atau pesan, Pada iklan pada frame tersebut memperlihatkan unsur visual gelembung, logo Sprite, visual stilasi lemon, unsur kata dan kalimat Hay guys! Ayo berfikir jernih, dan vocal voice yang sama.

2. Relasi unsur sinaktik frame (-0.30 s): Prinsip sinaktik melihat relasi unsur pembentuk pesan secra keseluruhan (persepsi keseluruhan tanda). Berdasarkan unsur analitik hubungan elemen unsur yang telah diadeskripsikan sebelumnya (unsur analitik) dapat disimpulan secara sinaktik bahwa relasi kandungan pesan kalimat "berpikir jernih" dinegasikan melalui dominasi unsur kejernihan Sprite Unsur visual air dan gelembung. Sedangkan Unsur lainnya sebagai sebuah identitas "Sprite".

3. Hasil kesimpulan relasi unsur: Jika disimak dalam pandangan Sinaktik secara utuh, kumpulan komponen unsur analitik tersebut memberikan gambaran visualisasi identitas Sprite (logo) dalam muatan kejernihan komponen gelembung air. Kesimpulan ini berdasarkan interpretasi hubungan relasi antar unsur analitik maupun sinaktik (bersifat pragmatis).

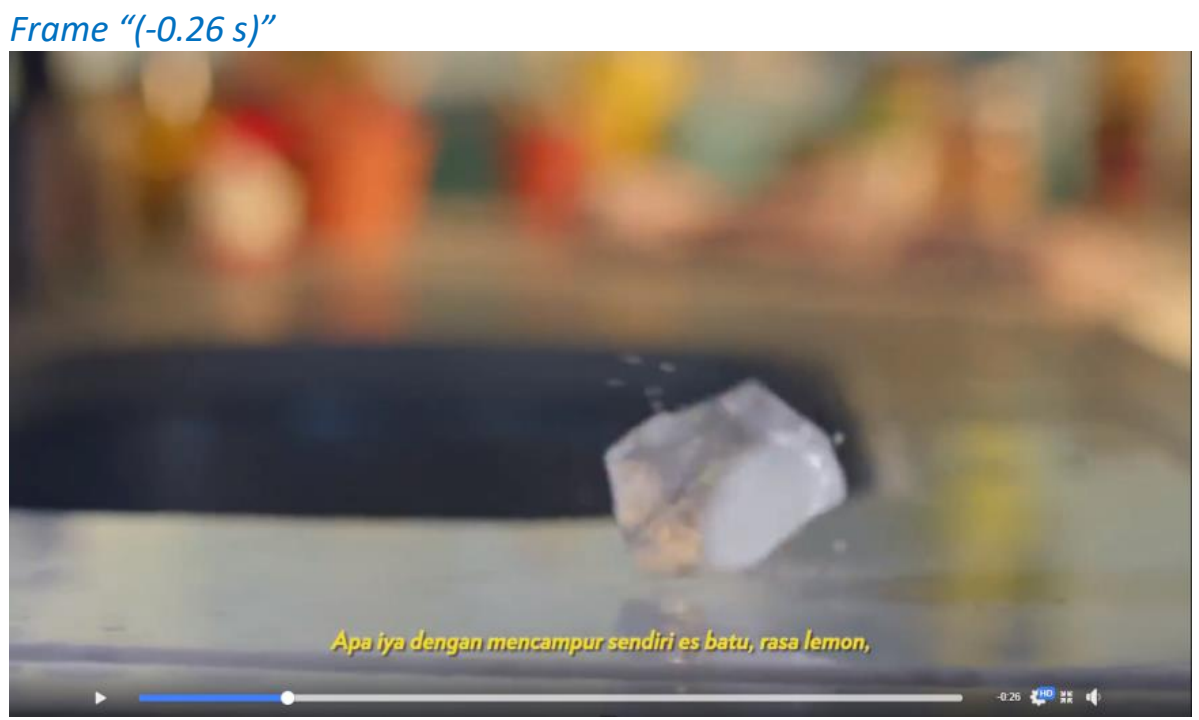

Gambar 2. Potongan iklan -0.26 Detik (Sumber

https://web.facebook.com/Spriteid/videos/872091522923549/?v=872091522923549)

Potongan kalimat pada menit ke (-0.26 s) memiliki narasi "Apa iya dengan mencampur sendiri es batu, ras lemon". Lanjutan kalimat ini melanjutkan konteks kelimat sebelumnya "berpikir jernih" yang secara hipotesa menyiratkan ajakan dan rasa penasaran. Jika ditelaah dengan relasi-relasi unsur baik analitik dan sinaktik dapat diuraikan seperti berikut;

1. Relasi Analitik frame (-0.26 s) secara analitik, dalam frame tersebut memiliki unsur visual batu es dengan gerakan terhambur, terdapat unsur visual wastafel sebagai pembangun suasana dapur meskipun dengan penyajian blur. Unsur lainnya, adalah kata " apa iyya dengan mencampur sendiri es Batu, rasa lemon begitupun dengan kalimat vocal voice . 
2. Relasi Sinaktik frame (-0.26), jika semua komponen unsur analitik diperhatikan secara unsur sinaktik (yang saling berhubungan) pada durasi tersebut memperlihatkan gerakan es batu yang bertaburan pada wastafel dengan negasi dari kalimat "apa iyya dengan mencampur sendiri es Batu, rasa lemon begitupun dengan kalimat vocal voice .

3. Kesimpulan relasi Unsur: melalui unsur-unsur Analitik dan unsur sinaktik pada frame (0.26) tersebut mengalami pembacaan bahwa Unsur Batu es secara iconical menjelaskan maksud text "mencampur baru es", Unsur tekst dan kalimat "sendiri" dinegasikan dengan unsur sinektik nuansa video tanpa menampilkan unsur manusia yang menjatuhkan batu es tersebut. Sehingga unsur kalimat yang disampaikan oleh vocal voice ditegaskan oleh unsur kata dan visual. Menariknya adalah dalam kalimat unsur "lemon" justru tidak dinegasikan dengan visual apapun di frame, melaikan unsur visual tersebut telah hadir sebelumnya di frame pertama $(-0.30 \mathrm{~s})$. Unsur kreatif pada frame ke dua terlihat dari dukungan visual yang telah ditanam di frame sebelunya sehingga penyimak dapat memahami bahwa iklan ini sedang menjelaskan "Sprite rasa lemon" yang dicampur dengan batu es. Kekuatan unsur gerakan visual juga sangat mendukung tersampaikannya imajinasi "seakan penyimak merasakan sendiri sensasi mencampur batu es tersebut dengan Sprite rasa lemon". Hal ini terlihat pada pilihan unsur menghaburkan es batu sehingga salah satu es terpental dan terlihat begitu dramatik.

Frame $(-0.23 s)-(-0.22 s)$

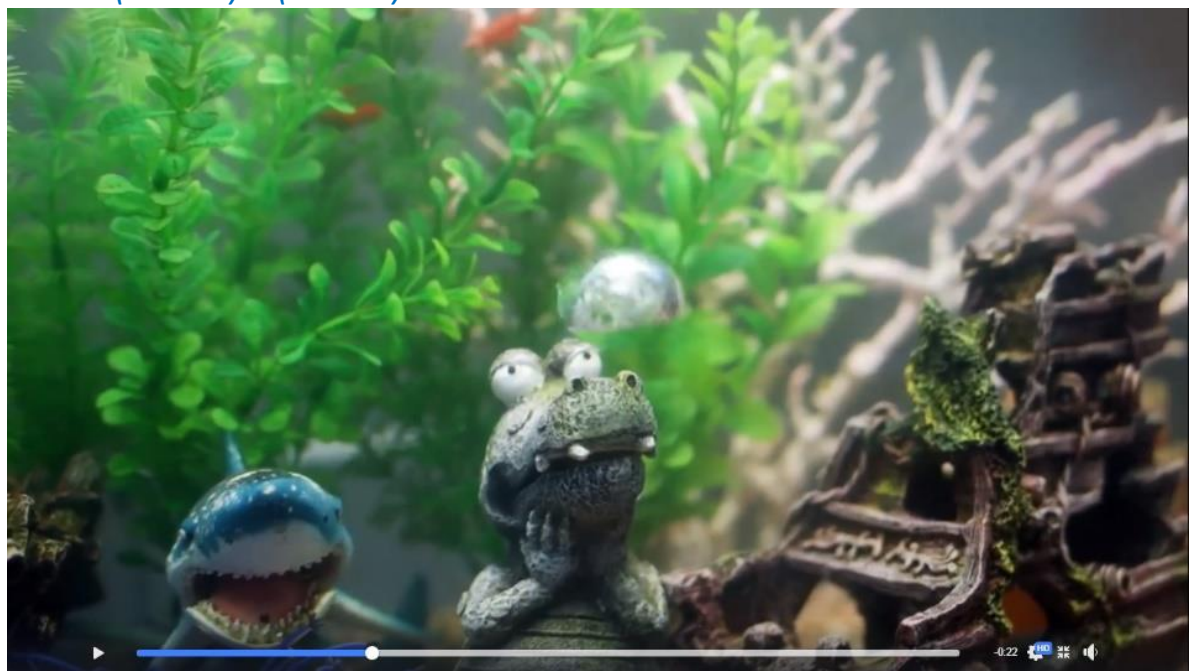

Gambar 3. Potongan iklan -0.23 Detik (Sumber

https://web.facebook.com/Spriteid/videos/872091522923549/?v=872091522923549)

Unsur yang lebih padat dijumpai pada frame ke tiga ini, yakni di durasi (-0.23 s)- (-0.22 s) dengan kalimat "dan gelembung, bisa seenak dan senyegerin segelas Sprite?. Pesan yang ditampilkan pun masih merupakan lanjutan potongan dari pesan dari frame-frame sebelumnya. Untuk memahami peran-peran unsur yang ada pada frame tersebut, maka akan dijelaskan melalui relasi-relasi sebagai berikut;

1. Relasi unsur analitik frame $(-0.23 \mathrm{~s})-(0.22 \mathrm{~s})$, pada frame ini memiliki unsur visual analitik yang beragam dengan tampilan suasana dalam air. Secara seksama, pada frame ini menampilkan unsur visual yakni miniatur Hiu, Miniatur Buaya, pepohonan berwarna hijau, ranting putih, miniatur serpihan bangunan, ikan, gelembung yang keluar dari mulut buaya. 
Sedangkan unsur kalimat dalam frame tersebut adalah "dan gelembung, bisa seenak dan se-nyegerin segelas Sprite" diiringi dengan vocal voice yang sama.

2. Relasi unsur sintakmatik $(-0.23 \mathrm{~s})-(0.22 \mathrm{~s})$, relasi unsur analitik telah menguraikan secara rinci semua unsur yang digunakan dalam frame $(-0.23 \mathrm{~s})-(0.22 \mathrm{~s})$, secara sintakmatik relasi-relasi tanda ini saling berhubungan ntuk menciptakan pesan yang ingin dicapai. Jika ingin ditelaah lebih teliti perlu dipahami motif pesan yang ingin disampaikan pada frame ini. Hal tersebut ditelusuri dari pesan kalimat terlebih dahulu yakni "dan gelembung, bisa seenak dan se-nyegerin segelas Sprite" diiringi dengan vocal voice yang sama. Kalimat tersebut merupakan lanjutan konteks dari frame 2. Frame "(-0.26 s)" yakni mencampur es batu dengan negasi visual es batu. Berdasarkan unsur kalimat kedua frame tesebut memiliki motif pesan untuk mengajak imajinasi pemirsa untuk membayangkan mencampur es batu dan gelembung dapat menyegarkan. Secara Sintakmatik hubungan semua unsur yang ada pada frame tersebut menyampaikan motif pesan kesegaran melalui negasi unsur gelembung yang keluar dari mulut miniatur buaya. Selebihnya unsur yang lain sebagai pembangun suasana penguatan imajinasi pemirsa. Jika masuk ke ranah Interprestasi, maka unsur-unsur tersebut akan memiliki arti yang variatif. Namun secara pandangan relasi unsur, kesimpulan yang dapat ditarik hanya terbatas pada relasi-relasi unsur yang pada pada frame tersebut.

3. Secara keseluruhan relasi unsur-unsur baik yang dilihat secara analitik dan sintakmatik, pesan kesegaran yang ingin disampaikan pada frame iklan Sprite tersebut memiliki reaksi unsur yang berupaya membangun imajinasi pemirsa untuk mengalami pengalamanpengalaman kesegaran dalam dirinya sendiri. Kehadiran visual gelembung sebagai indekstual pesan gelembung itu sendiri, sedangkan visual lainnya dikemas dengan negasi interpretatif. Jika ingin lebih lanjut membahas ke interpretasi dan persepsi pembacaan pemirsa maka relasi unsur tak cukup untuk membahasnya (perlu teori yang lain). Relasi unsur hanya akan membahas mengenai hubungan-hubugan unsur yang ada dalam media komunikasi visual secara kreatif. Pada frame tersebut memiliki unsur yang menarik dan sederhana dalam menampilkan setiap pesan yang akan disampaikan.

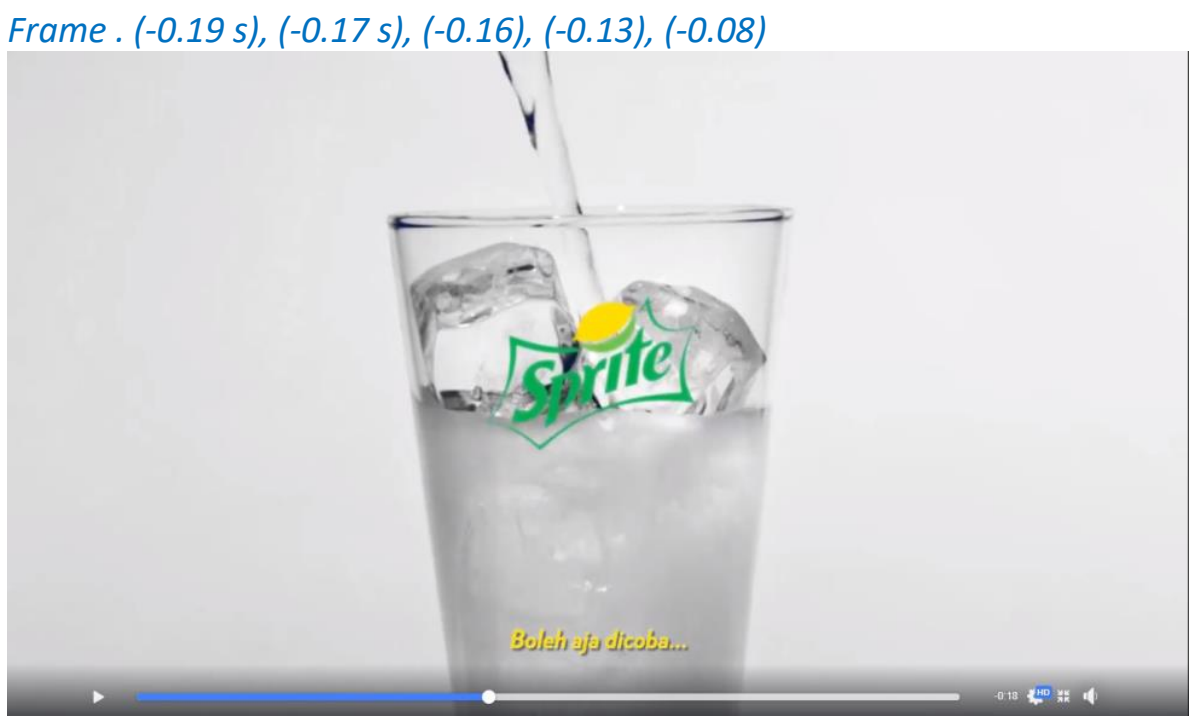

Gambar 4. Potongan iklan (-0.19 s), (-0.17 s), (-0.16), (-0.13), (-0.08) (Sumber https://web.facebook.com/Spriteid/videos/872091522923549/?v=872091522923549) 
Frame ini memiliki durasi yang mendominasi dibanding dengan frame yang lainnya, dengan kalimat yang cukup panjang dan negasi unsur visual yang sedikit. Menariknya adalah dengan menampikan relasi unsur-unsur visual yang sedikit, namun inajinasi pemirsa akan kesegaran seakan sampai pada tahap klimaks di frame ini. Secara deskriptif durasi pada frame ini mengambil kurang lebih $3 / 4$ dari kesluruhan video. Beberapa potongan kalimat juga diambil dari frame sebelunya yakni "segelas Sprite". Pada kalimat tersebut unsur visual ini dimulai. Untuk pembahasan yang lebih analitik dapat dilihat pada pembehasan unsur-unsur berikut;

1. Relasi Unsur analitik, secara analitik unsur-unsur visual yang terdapat pada frame tersebut adalah sebuah gelas, background putih, es batu, cairan Sprite, gelembung pada gelas dengan gerakan zoom, efek visual dengan gerakan zoom, unsur kalimat "segelas Sprite (potogan kalimat frame sebelumnya). (-0.19 s), Boleh aja dicoba, (-0.17 s) Tapi nyatanya susah, (-0.16) Menurut kamu info ini ngga penting, (-0.13) Nyatanya kamu jadi nonton iklan ini selama lebih dari 20 detik, $(-0.08)$ dan sekarang kamu jadi haus dan pengen minum Sprite.

2. Relasi Unsur Sinaktik, pada relasi sinaktik unsur yang akan dibahas pada frame ini lebih padat terutama pada bagian unsur kalimat. Pada kata "segelas Sprite" dinegasikan melalui gelas (dengan format indekstual), kalimat selanjutnya justru tidak dinegasikan dengan unsur-unsur apapun, menariknya adalah unsur kata "boleh aja dicoba, nyatanya susah" memiliki interprestasi hanya untuk pemirsa. Sedangkan unsur untuk menjelaskan pesan tersebut sama sekali susah untuk ditemukan maksudnya. Pada dasarnya antara unsur pesan visual dan kalimat secara kreatif ditampilkan tanpa adanya hubungan negasi relasi unsur baik analitik maupun sinaktik. Namun, pesan kesegaran yang ditampilkan oleh unsur-unsur visual segelas Sprite yang dikemas dengan tampilan gerakan zoom telah menjadi klimaks bagi pemirsa. Unsur Kalimat "boleh aja dicoba, nyatanya susah" justru hadir sebagai provokasi imajinasi bagi pemirsa untuk segera merealisasikan pesan kesegaran tersbut. Selanjutnya pada unsur kalimat "Menurut kamu info ini ngga penting, $(-0.13)$ Nyatanya kamu jadi nonton iklan ini selama lebih dari 20 detik, $(-0.08)$ dan sekarang kamu jadi haus dan pengen minum Sprite" memutuskan klimaks imajinasi pemirsa untuk kembali menyadari bahwa unsur viual yang ditampilkan pada frame tersebut bukanlah kenyataan.

3. Dalam konteks kreativitas penggunaan unsur, pada frame ini menyajikan yang sangat menarik dalam konten iklan. Secara teori penggunaan unsur, baik unsur kalimat maupun visual yang ditampilkan memberikan efek yang kuat dalam membawa pemirsa ikut larut dalam imajinasi pesan.

Analisis relasi unsur baik analitik dan sinaktik pada iklan Sprite kenyataan yang menyegarkan dapat dibedakan menjadi dua kategori unsur. Pertama adalah unsur visual maupun unsur kalimat. Kendati peranan unsur visual memiliki muatan yang berbeda dengan kalimat, namun pada iklan tersebut kedua unsur tersebut saling berelasi untuk menghantarkan imajinasi pemirsa tentang pesan Kesegaran. Lantas bagaimana kinerja unsur-unsur yang hadir dalam iklan tersebut dapat menyampaiakan pesan "kenyataan yang menyegarkan'?. Melalui analisis yang telah dilakukan sebelumnya memberikan jawaban kekuatan penggunaan unsur idekstual menggiring imajinasi pemirsa untuk merasakan kenyataan tersebut. Pengertian unsur Indekstual merupakan salah satu kajian bentuk tanda pragmatis yang hadir dari pola Semiotika Charles Sanders Pierce.

Dapat disimpulkan bahwa, untuk menyampaikan pesan "kenyataan yang menyegarkan" tidak perlu memunculkan unsur-unsur visual yang filosofis ataupun simbolik. Dengan menampilkan unsur visual untuk menjelaskan maknanya sedir telah memiliki 
keberhasilan dalam menyampaikan pesan. Hal ini terlihat dari kata "gelembung" dengan negasi idekstual visual gelembung. Pemirsa tidak perlu jauh memikirkan gelembung yang seperti apa, namun unsur gelembung yang telah dihadirkan dalam visual frame tersebut telah menjadi pesan yang akurat.

\section{PENUTUP}

Dalam kajian relasi unsur pesan pada iklan Sprite "kenyataan yang menyegarkan" disimpulkan bahwa, terdapat kekuatan unsur yang saling mendukung baik unsur visual maupun unsur kalimat meskipun dengan pesan yang berbeda, Menagapa demikian? melalui frame (-0.19 s), (-0.17 s), (-0.16), (-0.13), (-0.08) hanya menapilkan relasi unsur yang sama dengan pesan kalimat yang begitu panjang. Unsur visual bekerja dalam menggiring imajinasi pemirsa, sedangkan kalimat membawa pesan propokatif. Provokatif yang dimaksudkan adalah dalam kondisi pemirsa meyaksikan kenyataan kesegaran dalam imajinasi unsur visual, pesan kalimat hadir membawa ke kenyataan yang sebenarnya. Sehingga pada potongan kalimat "Menurut kamu info ini ngga penting, (-0.13) Nyatanya kamu jadi nonton iklan ini selama lebih dari 20 detik, (-0.08) dan sekarang kamu jadi haus dan pengen minum Sprite, (-0.2) Sprite nyatanya Nyegerin" memberikan kesadaran bahwa hal tersebut hanyalah sebuah visual segelas Sprite. Keberhasilan iklan ini adalah melalui kedua relasi unsur pesan "kenyataan yang menyegarkan ", dapat dinegasikan dalam imajinasi unsur visual yang dikuatkan oleh unsur kalimat. Bahwasanya minuman Sprite dalam keadaan pesan visual pun kesegarannya terasa nyata meskipun unsur kalimat tidak memiliki info yang menarik.

\section{DAFTAR PUSTAKA}

Allport, Gordon Willard. Personality: A Psychological Interpretation. Henry Holt and Company, 1961.

Bogdan, Robert C and Sari Knopp Biklen. Qualitative Research for Education: An Introduction to Theory and Methods. Allyn and Bacon, 1998.

Budiman, Kris. Semiotika Visual: Konsep Isu. Dan Problem Ikonisitas. Jalasutra, 2011.

Creswell, John W. Research Design Pendekatan Kualitatif, Kuantitatif, Dan Mixed. Pustaka Pelajar, 2010.

Denzin, Norman K. and Yvonna S. Lincoln. The Sage Handbook of Qualitative Research. SAGE Publications, 2009.

Kirk, S. et al. Educating Exceptional Children. 5th edition, Houghton Mifflin Company, 1986.

Mitaharoh, Lailatul. "Efektifitas Iklan Sprite Versi Cak Lontong Kenyataan Yang Menyegarkan Menggunakan Metode Epic." Management, vol. Sarjana (S1), Skripsi, Universitas Muhammadiyah Jember, 2017.

Sugiharto, I. Bambang. Untuk Apa Seni? Pustaka Matahari, 2015. 
Jurnal Desain, Vol.7, No.3, Mei-Agustus 2020, 243-256

http://dx.doi.org/10.30998/jd.v7i3.6383

Sugiyono. Metode Penelitian Pendidikan:(Pendekatan Kuantitatif, Kualitatif Dan $R \& D)$. Alfabeta, 2009. 